\title{
Risk Factors of Hypertension in the Elderly
}

\author{
$1^{\text {st }}$ Wilis Sukmaningtyas \\ Study Program D3 \\ Midwifery Faculty Of Health \\ Harapan Bangsa University \\ wilissukmaningtyas@uhb.ac.id
}

\author{
$2^{\text {nd }}$ Tin Utami \\ Study Program D3 \\ Midwifery Faculty Of Health \\ Harapan Bangsa University \\ tinutami@uhb.ac.id
}

\begin{abstract}
Hypertension is a noncommunicable disease that gets the nickname "The Silent Killer", because of its characteristics that cause death without any previous symptoms. The number of elderly population in Indonesia according to 2016 Susenas data is 22.4 million people or $8.69 \%$ of the population, and hypertension is the most common disease $(\mathbf{5 7 . 6 \%})$. Many factors can cause hypertension including family history, history of previous hypertension, and smoking. The purpose of this study was to analyze the risk factors for hypertension in the elderly in Tambaksogra Village, Sumbang District, Banyumas Regency. This type of research is analytic descriptive research with a retrospective approach. The population in this study were all the elderly who had hypertension recorded from January to July 2019 totaling 217 respondents. The sampling technique used is total sampling. The results of this study were processed using the Chi Square test (table 2x2). The results of this study found that there was a relationship between family history and hypertension history prior to hypertension in the elderly with $p$ values of each $p$ value <alpha $(0,000<0.05)$ and $(0.001<0.05)$, while the smoking habit factor found no relationship with the value of $p$ value $>$ alpha $(0,700>0.05)$.
\end{abstract}

Keywords: family history, history of hypertension, smoking, elderly

\section{INTRODUCTION}

Hypertension is a "silent killer" where symptoms can vary in each individual and is almost the same as other disease symptoms. Symptoms it is a headache/severe sense in the nape, minerals (vertigo), heart palpitations, easy ielah, blurred vision, ringing ears (tinnitus), and nose bleed [1]. In general, hypertension can be defined as systolic pressure more than $140 \mathrm{mmHg}$ and diastolic pressure more than $90 \mathrm{mmHg}$. Human blood pressure naturally fluctuates throughout the day and will be a problem if the blood pressure is persistent [2]. Hypertension is also a major risk factor in the occurrence of cardiovascular disease. If not handled properly, hypertension can cause stroke, myocardial infarction, heart failure, dementia, renal failure, and vision disorders. The World Health Organization (WHO) estimates that hypertension causes 9.4 million deaths and covers $7 \%$ of the world's disease burden [3].

The cause of hypertension can be classified into two namely, 1) essential hypertension (primary) occurs about 95\%, and direct causes are not known clearly; 2) secondary hypertension occurs around 5\%, such as hormonal problems, large blood vessel narrowing problem or narrowing of kidney vessels [4]. Hypertensive disease annually occurs, not only in Indonesia but also in the world.. A total of 1 in 4 adults or as many as 1 billion people suffer from hypertensive disease. In fact, the estimated number of patients with hypertension will increase to 1.6 billion by 2025 . Approximately $10-30 \%$ of adult population in almost all countries have hypertension, and about $50-60 \%$ of adult population can be categorized as a major majority whose health status will be better when it can be controlled by blood pressure [5]. 
According to the Kemenkes report year 2013, that hypertension is the cause of death number 3 after stroke and tuberculosis, where the proportion of mortality reaches $6.7 \%$ of the mortality population at all ages in Indonesia. The result of basic health Research (RISKESDAS) shows the prevalence of hypertension based on measurement results in population aged $\geq 18$ years nationwide reached $25.8 \%$ in 2013 and increased in 2018 by $34.1 \%$ [6]. Susenas 2016 records the number of elderly people in Indonesia as much as 22.4 million people or $8.69 \%$ of the population, and hypertension is the most suffered disease (57.6\%). Research conducted by Arifin about the factors related to the incidence of hypertension in the elderly group in the working area of the afternoon health care I Badung Regency Year 2016, obtained results there is a meaningful relationship between genetic, Exercise and stress levels with the incidence of hypertension, while in the sex factor, obesity, smoking and alcohol consumption there is no meaningful relationship with the incidence of hypertension [7].

In line with research conducted by Wahyuningsih about the factors that affect hypertension in the elderly ie age factor, exercise habits, type of personality and obesity is a factor that affects the incidence of hypertension [8]. The same is done by Fitria about risk factors related to incidence of hypertension in adolescents in the work area of inpatient Puskesmas Sidomulyo Kota Pekanbaru in 2012, obtained a significant relationship between the history of Heredity, obesity and physical activity in the event of hypertension while smoking and sodium intake does not have a meaningful relationship [9].

\section{MATERIALS AND MethODS}

This type of research is a descriptive analytical research with a retrospective approach, which is the research to identify the effects (illness or health status) at this time then identified risk factors that occurred time ago [10]. Research was conducted in July 2019. The population in this study was the entire elderly who suffered from hypertension since January - July 2019 in the village of Tambak Sogra of 217 respondents and the entire population was made a sample. The data used in this research is the secondary data obtained from the Posbindu village data of Tambak Sogra which includes the identity of the respondent, the history of hypertensive respondents, the history of hypertension in families, smoking habits and incidents Hypertension. Data analysis is used to process data using the Chi Square test ( $2 \times 2$ tables) with $\alpha=0.05$.

\section{RESULT}

\subsection{Elderly characteristics}

The results of the study, obtained that the most respondents to the characteristics of the early elderly age of 171 respondents $(78.8 \%)$, female gender as many as 137 respondents $(63.1 \%)$, no previous hypertension history of 194 respondents (89.4\%), There is no history of hypertension in families as much as 169 respondents $(77.9 \%)$, not having a habit of smoking as many as 161 respondents (74.2\%) And respondents who did not suffer from hypertension as much as 127 respondents $(58.5 \%)$ (Table 1).

\subsection{Correlation of hypertension factors}

Respondents who did not have a history of hypertension and did not suffer from hypertension as much as 121 respondents (55\%), as well as respondents who had a history of hypertension and suffered a hypertension of 6 respondents $(2.8 \%)$. Chi Square test Results obtained $p$ value $=0.001<\alpha=0.05$, it can be interpreted there is a significant relationship between the previous history of hypertension and the incidence of hypertension (table 2).

Respondents who had no history of hypertension in the family and did not suffer from hypertension as much as 112 respondents $(61.6 \%)$, as well as respondents who had a history of hypertension in the family and did not suffer from hypertension as much as 15 respondents (6.9\%) Chi Square test Results obtained $\mathrm{p}$ value = $0.000<\alpha=0.05$, this indicates there is a significant link between the history of hypertension in families with the incidence of hypertension (table 3 ).

In table 4 , respondents did not smoke and did not suffer from hypertension as much as 93 respondents (42.9\%), as well as the respondents who smoked and suffered a hypertension of 22 respondents (10.1\%).

Chi Square test Results obtained P value $=0.700>\alpha=$ 0.05 , this indicates there is no significant relationship between smoking habits and the incidence of hypertension. 
Table 4: Habit of smoking with hypertension in elderly

Table 1: Distribution of age, gender, history of $\begin{array}{ll}\begin{array}{c}\text { hypertension, } \\ \text { hypertension } \\ \text { elderly }\end{array} & \begin{array}{l}\text { family } \\ \text { and history of } \\ \text { smoking in }\end{array} \\ \text { hypertension } & \end{array}$

\begin{tabular}{cccc}
\hline Characteristics & Category & f & \% \\
\hline \multirow{2}{*}{ Age } & Early elderly Late & 17146 & 78.8 \\
& elderly & & 21.2 \\
\hline \multirow{2}{*}{ Gender } & Male & 80 & 36.9 \\
& Women & 137 & 63.1 \\
\hline History of & No Have & 19423 & 89,4 \\
Hypertension & & & 10,6 \\
\hline $\begin{array}{c}\text { History of family } \\
\text { Hypertension }\end{array}$ & No Have & 16948 & 77.9 \\
\hline \multirow{2}{*}{ Smoking } & & & 22.1 \\
\hline \multirow{3}{*}{ Hypertension } & No Smoking & 16156 & 74.2 \\
& Smoking & & 25.8 \\
\hline & No hypertension & 12790 & 58.5 \\
& Hypertension & & 41.5 \\
& Total & 217 & 100.0
\end{tabular}

Source: Secondary Data

Table 2: Hypertension History relations with hypertension in elderly

\begin{tabular}{|c|c|c|c|c|c|c|c|}
\hline \multirow{3}{*}{$\begin{array}{c}\text { History of } \\
\text { Hypertension }\end{array}$} & \multicolumn{4}{|c|}{$\begin{array}{r}\text { Hypertension } \\
\end{array}$} & \multirow{2}{*}{\multicolumn{2}{|c|}{ Total }} & \multirow{3}{*}{$\begin{array}{c}p \\
\text { value }\end{array}$} \\
\hline & \multicolumn{2}{|c|}{$\begin{array}{c}\text { No } \\
\text { hypertension }\end{array}$} & \multicolumn{2}{|c|}{ Hypertension } & & & \\
\hline & f & $\%$ & f & $\%$ & f & $\%$ & \\
\hline no & 121 & 55.8 & 73 & 33.6 & 194 & 89.4 & 0,001 \\
\hline have & 6 & 2.8 & 17 & 7.8 & 23 & 10.6 & \\
\hline Total & 127 & 58.5 & 90 & 41.5 & 217 & 100 & \\
\hline
\end{tabular}

Table 3: Family hypertension History relationship with hypertension in elderly

\begin{tabular}{|c|c|c|c|c|c|c|c|}
\hline \multirow{2}{*}{$\begin{array}{l}\text { History of } \\
\text { Hypertensior }\end{array}$} & \multicolumn{4}{|c|}{ Hypertension } & \multirow{2}{*}{\multicolumn{2}{|c|}{ hypertension }} & \multirow[b]{2}{*}{ value } \\
\hline & \multicolumn{3}{|c|}{ hypertension } & $p$ family & & & \\
\hline & f & $\%$ & $\mathbf{f}$ & $\%$ & $f$ & $\%$ & \\
\hline no & 112 & 51.6 & 57 & 26.3 & 169 & 77.9 & 0,000 \\
\hline have & 15 & 6.9 & 33 & 15.2 & 48 & 22.1 & \\
\hline Total & 127 & 58.5 & 90 & 41.5 & 217 & 100 & \\
\hline
\end{tabular}

\begin{tabular}{|c|c|c|c|c|c|c|c|}
\hline \multirow{3}{*}{ Smoking } & \multicolumn{4}{|c|}{ Hypertension } & \multirow{2}{*}{\multicolumn{2}{|c|}{ Total }} & \multirow{3}{*}{$p$ value } \\
\hline & \multicolumn{2}{|c|}{$\begin{array}{c}\text { No } \\
\text { hypertension }\end{array}$} & \multicolumn{2}{|c|}{$\begin{array}{c}\text { No } \\
\text { hypertension }\end{array}$} & & & \\
\hline & f & $\%$ & f & $\%$ & $\mathbf{f}$ & $\%$ & \\
\hline $\begin{array}{c}\text { No } \\
\text { Smoking }\end{array}$ & 93 & 42.9 & 68 & 31.3 & 161 & 74.2 & 0,700 \\
\hline Smoking & 34 & 15.7 & 22 & 10.1 & 56 & 25.8 & \\
\hline Total & 127 & 58.5 & 90 & 41.5 & 217 & 100 & \\
\hline
\end{tabular}

\section{DISCUSSION}

Hypertension or better known as high blood pressure disease is a condition in which a person has increased blood pressure above normal resulting in an increase in pain and mortality rate (mortality). Uncontrolled hypertensive disease can cause body organs to become damaged [11].

Age is one of the important variables of the human being because of pain and death figures almost all circumstances indicate the relationship with the age [12] and people who are 40 years old are usually susceptible to increasing blood pressure can gradually become hypertension as their age grows [2]. The respondents of this research are at most early age. According to the Ministry of Health, the age of early age was $46-55$ years old while the late elderly $56-65$ [13].

The results of the research conducted by Dedullah at small Motoboi Sub-district of Kotamobagu south of Kotamobagu, the incidence of hypertension is more experienced by respondents at the age of $\geq 43$ years as much as 50 respondents (33.3\%) [14]. In line with the research carried out factors related to blood pressure, research results that age $\geq 40$ years have a risk of hypertension at 11.71 times compared with the age of < 40 year [15].

In addition to age factors, gender is also one of the factors that increase the incidence of hypertension. The respondents in this study were the most women of 137 respondents (63.1\%). According to a woman's gender manuntung more hypertension in age more than 50 years, because in that age a woman has experienced menopause and higher levels of stress, while on the gender of men more experienced Hypertension at the age of less than 50 years, because in that age a man has more activity than women [2]. 
The research conducted by Arifin about the factors related to hypertension in the elderly group in the working area of the UPT Health Center in the Badung district, obtained by the results that the number of elderly patients who had more hypertension in Female elderly, i.e., 49 people compared to elderly malegender. A total of 80 elderly women with female gender, among them 49 people $(61.3 \%)$ who have hypertension and 31 people (38.8\%) That does not suffer from hypertension [7].

In line with Azhari research on the factors related to hypertension in Makrayu Puskesmas West Ilir District II, Palembang, obtained $\mathrm{p}$ value $=0.026$ with $\alpha$ value $=$ $0.05, \mathrm{p}<\alpha(\mathrm{H} 0$ rejected $)$ means indicating there is a relationship between the The incidence of hypertension with the value of Odds ratio $(\mathrm{OR})=2.708$, this means that respondents of female gender have an opportunity of 2.7 times to be exposed to hypertensive disease compared to male-gender respondents. With confidence level $(95 \% \mathrm{CI})=1,1976,126[16]$.

\section{History of Hypertension with Incidence of Hypertension}

In table 2 respondents who do not have a history of hypertension is largely experiencing hypertensive disease by $55.8 \%$, statistic test results obtained $\mathrm{p}=$ 0.001 value which means there is a meaningful relationship between the history of hypertension and Genesis Hypertension in elderly in Tambak Sogra village.

In line with research conducted by Ratumbuysang and Manado on risk factors related to incidence of hypertension in pregnant women in Poly hospital ObsGin mental hospitals Prof. Dr. V. L. Ratumbuysang City of Manado, namely there is a Relationship between hypertensive history and incidence of hypertension in pregnant women with value $\mathrm{P}=0,002$ $(\mathrm{P}<0,005)$ [17].

The history of hypertension experienced before can be revived because of the treatment that is being undergone at the time, some medicines can cause hypertension as in the group of drugs corticosteroids. Hypertension can also be influenced by life patterns such as excessive consumption of salt or lack of exercise, sports such as cycling, jogging and aerobic that can facilitate the circulation of blood so that it can lower blood pressure [11].

Repeated incidence of hypertension can be termed as relapse. Recurrence is a state of the client hypertension where the same symptoms arise as before and cause the client hypertension to be treated again [18]. Hypertension can relapse, because overall hypertension can not be cured, but with proper management of hypertension can be controlled and can reduce recurrence. The combination of lifestyle modification and antihypertensive drugs can usually keep blood pressure in a range that will not damage the heart and other organs [19].

Recurrence of hypertension occurs because of various factors that trigger physical and psychological stress, improper diet (salt height), smoking habit, alcohol consumption, and sport. It is also not much different from the factors that affect the onset of hypertension including genetic, age, sex, ethnicity, obesity, diet intake pattern of high salt, smoking and personality types [20], [21].

According to the research conducted ainiyah about attitude relation about hypertension with recurrence frequency in patients with hypertension, there is a significant relationship between the attitude about hypertension and frequency of recurrence in sufferers Hypertension with a value of $\mathrm{P}(0.002)$ is smaller than $\alpha(0.05)$ then Ho is rejected and Ha is accepted and the magnitude value is 0467 (between 0.40-0.599) indicating that the strength of the correlate is being [22].

\section{History of Hypertension Family with Incidence of Hypertension}

In table 3, respondents who did not have a history of hypertension in the family and did not suffer from hypertension as much as 112 respondents $(61.6 \%)$. Chi Square test Result obtained a P value of $0.000<0.05$, this indicates there is a significant link between the history of hypertension in the family with the incidence of hypertension. In line with research conducted by Dedullah that there is a connection between the descendants of hypertension with hypertensive events in the community in the small Motoboi Sub District Kotamobagu south of 
Kotamobagu city, $\mathrm{p}=0.000$ with Error rate 0.05 and OR of 39.885 which means that the descendants of hypertension have a risk of 39.885 times greater cause of hypertensive incidence than those who do not have the descendants of hypertension [14]

Hypertension is one of the most complex genetic disorders. Essential hypertension is usually associated with genes and genetic factors, where many genes contribute to the development of hypertensive disorders. Genetic factors donate $30 \%$ to changes in blood pressure in different populations. The role of genetic factors on the onset of hypertension is more in monozygous twins (one egg cell) than heterozygous (different egg cells). A sufferer with genetic properties of primary (essential) hypertension when left naturally without therapeutic intervention, with its environment will cause its hyperlink to develop and in about 30-50 years will arise signs and symptoms [23].

Suiraoka in his book says that the hereditary factor has a very large role in the emergence of hypertension. This is evident with the discovery that more incidence of hypertension occurs in monozygous twins compared to heterozygous (derived from different egg cells) [24]. There is a history of hypertension in both parents, enlarging the suspicion towards primary hypertension. According to Nurkhalida in Alifariki, people with family history who have hypertension more often suffer from hypertension and have a higher risk of hypertension 2-5 fold especially in primary hypertension. Data statistic proves if a person has a history one of his parents suffer from untransmitted diseases then it is possible throughout his descendants life has a chance of $25 \%$ infected with the disease. If both parents have an uncontagious disease then the likelihood of obtaining the disease is $60 \%$ [25].

Hypertension can occur in a family, and the risk of high blood pressure will increase based on age, race and ethnicity. Genetic factors, play a role in the occurrence of blood pressure, heart disease and other related conditions. The risk of hypertension can increase when there is a combination of hereditary factors and a choice of unhealthy lifestyles, such as smoking, and unhealthy food diets [26].

Strengthening the theory that has been submitted by a study conducted by Fitriana shows a significant relationship between the history of the lineage with the incidence of hypertension in inpatient Puskesmas work area Sidomulyo Pekanbaru City Year 2012 i.e. $\mathrm{P}=$ 0,000 and $\mathrm{OR}=7.68$ [9]. This is in line with the research conducted by Arifin namely there is a meaningful relationship between genetic with hypertensive events, $\mathrm{p}=0,019<0.05$, Value RP 1.1417 (RP > 1) which means elderly who have a history of hypertension in the family is Risk factors to suffer from hypertension 1.417 times greater than those who do not have a history of the family [7].

\section{Smoking with Incidence of Hypertension}

Table 4 shows that respondents who did not smoke and did not suffer from hypertension as much as $42.9 \%$. Chi Square test Results obtained a P value of $0.700>$ 0.05 , which means there is no significant link between smoking habits and the incidence of hypertension. In line with research conducted Wahyuningsih IE there is no relationship between smoking habit with the occurrence of smoking in the elderly in Kabregan Hamlet, Srimulyo, Piyungan, Bantul, Yogyakarta with a value of $\mathrm{P}=0,989>\alpha=0.05$ [8].

In this study smoking habit is not a risk factor of hypertension, it can happen because smoking is one of the risk factors that can be controlled or controlled by hypertension.

This research is in accordance with the research conducted by Manimunda namely although the use of tobacco is very high among the people of Nicobarese but it does not add to the risk of hypertension, and the majority of smoked tobacco without smoke (almost $94 \%$ ), So the relationship between the use of tobacco without smoke and risk of hypertension has no evidence [27].

Hypertension can be caused by several things, the risk factors that can cause hypertension there are two of factors that can be controlled and that are not controllable. The controllable factor is 1) overweight or obese that can cause a fat-saving so that it can affect blood circulation; 2) Excessive consumption of salts, salt is holding water so as to raise blood pressure; 3 ) Less exercise in general tends to be overweight; 4) Stress, people who are stressed can stimulate the adrenaline hormones that can lead to a faster heart pulsed and capillary narrowing so that blood pressure increases; 5) Smoking and consumption of alcohol, nicotine contained in cigarettes can increase blood clots 
in the blood vessels and alcohol because of increased synthesis of catecholamine in large quantities can trigger the increase in blood pressure. A factor of incontrollable hypertension is 1) hereditary, $70-80 \%$ of people with hypertension are found there is a family history; 2) gender, male gender most risk of hypertension as it has a driving factor; and 3) age, hypertension attacked men at the age above 31 years while in women occurs after age 45 years (menopause) [25].

This is supported by the research conducted by Fitriana, i.e. there is no meaningful relationship between smoking and hypertension, $\mathrm{p}=0.11$ and obtained OR $>1$ value, but since number 1 is covered in CI then smoking behaviour is not a factor Risk of hypertension [9]. In line with research done by Arifin is the value of $\mathrm{P}=0,128(\mathrm{P}>0.05)$ which means there is no meaningful relationship between smoking with the incidence of hypertension, obtained by the value of RP-1.294 (RP > 1) [7].

Other studies have received different results from this study conducted by Situmorang on factors related to incidence of hypertension in inpatients at Sari Mutiara Medan General Hospital in 2014, a relationship With a factor of smoking with P: $0.000<0.05$. [28].

Dalimartha says that hypertension can be stimulated by the presence of nicotine in a cigarette that is smoked by a person. The results showed that nicotine can increase blood clots and blood vessels and nicotine can also cause the occurrence of impending on the walls of blood vessels [11].

\section{CONClusion}

5.1. There is hypertensive history relation to the incidence of hypertension in the elderly in Tambaksogra village $(\mathrm{p}=0.001<\alpha=0.05)$

5.2. There is a link between the family hypertension history and the incidence of hypertension in the elderly in Tambaksogra village $(\mathrm{p}=0,000<\alpha=$ 0.05 )

5.3. No connection between smoking activities and the incidence of hypertension in the elderly in Tambaksogra village $(p=0,700>\alpha=0.05)$

\section{REFERENCES}

[1] Kemenkes.RI, "Pusdatin Hipertensi," Infodatin, 2014.

[2] A. Manuntung, TERAPI PERILAKU KOGNITIF PADA PASIEN HIPERTENSI. Malang: Wineka Media, 2018.

[3] WHO, Global target 6: A 25\% relative reduction in the prevalence of raised blood pressure or contain the prevalence of raised blood pressure, according to national circumstances. Jenewa: World Health Organization., 2014.

[4] Kowalski.R.E, Terapi Hipertensi: Program 8 Minggu Menurunkan Tekanan Darah Tinggi dan Mengurangi Risiko Serangan Jantung dan Stroke Secara Alami, Cetakan I. Bandung: Qanita, 2010.

[5] M. Adib, Cara mudah memahami dan menghindari hipertensi, jantung, dan stroke. Yogyakarta: Dianloka Pustaka Populer, 2009.

[6] RISKESDAS, "Hasil Utama Riset Kesehatan Dasar 2018," Kementrian Kesehat. Republik Indones., 2018.

[7] M. H. B. M. Arifin, I. W. Weta, and N. L. K. A. Ratnawati, "FAKTOR-FAKTOR YANG BERHUBUNGAN DENGAN KEJADIAN HIPERTENSI PADA KELOMPOK LANJUT USIA DI WILAYAH KERJA UPT PUSKESMAS PETANG I KABUPATEN BADUNG TAHUN 2016," J. Med., vol. VOL. 5, p. NO.7, 2016.

[8] W. Wahyuningsih and E. Astuti, "Faktor Yang Mempengaruhi Hipertensi pada Usia Lanjut," J. Ners dan Kebidanan Indones., vol. 1, no. 3, p. 71, Mar. 2016.

[9] R. Fitriana, N. I. Lipoeto, and V. Triana, "Faktor Resiko Kejadian Hipertensi pada Remaja di Wilayah Kerja Puskesmas Rawat Inap Sidomulyo Kota Pekanbaru," J. Kesehat. Masy., 2013.

[10] S. A. Gahayu, Metodologi Penelitian Kesehatan Masyarakat, 1st ed. Yogyakarta: Deepublish, 2015.

[11] S. Dalimartha, B. T. Purnama, N. Sutarina, B. Mahendra, and R. Darmawan, Care Your Self Hipertensi: Pencehagan dan Pengobatan diri sendiri dengan: Pengaturan pola makan, 
herbal, terapi pijat, olah raga, yoga, meditasi, Cetakan 1. Jakarta: Penebar Plus, 2008.

[12] L. Maryani and M. Rizki, Epidemiologi Kesehatan. Yogyakarta: Graha Ilmu, 2010.

[13] Depkes RI, "Sistem Kesehatan Nasional," 2009.

[14] R. F. Dedullah, N. S. H. Malonda, W. Baren, and S. Joseph, "HUBUNGAN ANTARA FAKTOR RISIKO HIPERTENSI DENGAN KEJADIAN HIPERTENSI PADA MASYARAKAT DI KELURAHAN MOTOBOI KECIL KECAMATAN KOTAMOBAGU SELATAN KOTA KOTAMOBAGU."

[15] F. H. D. Anggara and N. Prayitno, "FaktorFaktor Yang Berhubungan Dengan Tekanan Darah di Puskesmas Telaga Murni Cikarang Barat Tahun 2012.," J. Ilm. Kesehat., 2013.

[16] M. H. Azhari, "Faktor-Faktor yang Berhubungan dengan Kejadian Hipertensi di Puskesmas Makrayu Kecamatan Ilir Barat II Palembang," J. Aisyah J. Ilmu Kesehat., vol. 2, no. 1, p. 23, Jun. 2017.

[17] P. V. L. Ratumbuysang and K. Manado, "Faktor-Faktor Risiko Yang Berhubungan Dengan Kejadian Hipertensi Pada Ibu Hamil Di Poli Klinik Obs-Gin Rumah Sakit Jiwa Prof. Dr. V. L. Ratumbuysang Kota Manado," J. Ilm. Bidan, 2014.

[18] Andri, "Kongres Nasional Skizofrenia V Closing The Treathment Gap for

Schizophrenia," kabarindonesia, 2008.

[19] A. Agoes, A. Agoes, and A. Agoes, Penyakit Di Usia Tua. Jakarta: EGC, 2011.

[20] A. Muhlisin et al., "ANALISIS PENGARUH FAKTOR STRES TERHADAP KEKAMBUHAN PENDERITA HIPERTENSI DI PUSKESMAS BENDOSARI SUKOHARJO."

[21] D. Ayu et al., "FAKTOR-FAKTOR YANG BERHUBUNGAN DENGAN KONTROL HIPERTENSI PADA LANSIA DI POS PELAYANAN TERPADU WILAYAH KERJA PUSKESMAS MOJOSONGO BOYOLALI."
[22] N. Ainiyah and L. Wijayanti, "HUBUNGAN SIKAP TENTANG HIPERTENSI DENGAN FREKUENSI KEKAMBUHAN HIPERTENSI PADA PENDERITA HIPERTENSI DI RW 06 KARAH KECAMATAN JAMBANGAN SURABAYA," J. Ilm. Keperawatan (Scientific J. Nursing), 2019.

[23] F. Rachman, H. P. JULIANTI, and D. PRAMONO, "BERBAGAI FAKTOR YANG BERHUBUNGAN DENGAN KEJADIAN HIPERTENSI PADA LANSIA,” 2011.

[24] I. Suiraoka, Media Pendidikan Kesehatan. Yogyakarta: Graha Ilmu, 2012.

[25] L. O. Alifariki, Epidemiologi Hipertensi (Sebuah Tinjauan Berbasis Riset). Yogyakarta: LeutikaPrio, 2019.

[26] CDC, "High Blood Pressure Fact Sheet," Div. Hear. Dis. Stroke Prev., 2016.

[27] S. P. Manimunda, A. P. Sugunan, V. Benegal, N. Balakrishna, M. V. Rao, and K. S. Pesala, "Association of hypertension with risk factors $\&$ hypertension related behaviour among the aboriginal Nicobarese tribe living in Car Nicobar Island, India," Indian J. Med. Res., 2011.

[28] P. R. Situmorang, "Faktor-Faktor yang Berhubungan dengan Kejadian Hipertensi pada Penderita Rawat Inap Di Rumah Sakit Umum Sari Mutiara Medan Tahun 2014," J. Ilm. Keperawatan, 2015. 